\title{
Effect of temperature on the anaerobic digestion of palm oil mill effluent
}

\author{
Wanna Choorit* \\ Biotechnology Program \\ School of Agricultural Technology \\ Walailak University \\ Tasala, Nakhonsithammarat 80160 Thailand \\ Tel: 6675672355 \\ Fax: 6675672302 \\ E-mail: cwanna@wu.ac.th \\ Pornpan Wisarnwan \\ Biotechnology Program \\ School of Agricultural Technology \\ Walailak University \\ Tasala, Nakhonsithammarat 80160 Thailand \\ Tel: 6675672303 \\ Fax: 6675672302 \\ E-mail: rombiot@hotmail.com
}

Financial support: Walailak University and the Southern Palm (1978) Co., Ltd.

Keywords: hydraulic retention times, mesophilic reactor, methane, organic loading rate, temperature variations, thermophilic reactor, volatile fatty acids.

Abbreviations: BOD: biochemical oxygen demand
COD: chemical oxygen demand
CSTRs: continuous stirred tank reactors
HRT: hydraulic retention time
OLRs: organic loading rates
POME: palm oil mill effluent
TKN: total Kjeldahl nitrogen
TS: total solid
TSS: total suspended solid
TVFA: total volatile fatty acid
UASFF: up-flow anaerobic sludge fixed film

Two continuous stirred tank reactors (CSTRs) each fed with palm oil mill effluent (POME), operated at $37^{\circ} \mathrm{C}$ and $55^{\circ} \mathrm{C}$, respectively, were investigated for their performance under varies organic loading rates (OLRs). The $37^{\circ} \mathrm{C}$ reactor operated successfully at a maximum OLR of $12.25 \mathrm{~g}[\mathrm{COD}] / \mathrm{L} / \mathrm{day}$ and a hydraulic retention time (HRT) of 7 days. The $55^{\circ} \mathrm{C}$ reactor operated successfully at the higher loading rate of $\mathbf{1 7 . 0 1}$ g[COD]/L/day and had a HRT of 5 days. The $37^{\circ} \mathrm{C}$ reactor achieved a $71.10 \%$ reduction of chemical oxygen demand (COD), a biogas production rate of $3.73 \mathrm{~L}$ of gas/L[reactor]/day containing $\mathbf{7 1 . 0 4 \%}$ methane, whereas the $55^{\circ} \mathrm{C}$ reactor achieved a $70.32 \%$ reduction of COD, a biogas production rate of $4.66 \mathrm{~L}$ of gas/L[reactor]/day containing $69.53 \%$ methane. An OLR of $9.68 \mathrm{~g}[\mathrm{COD}] / \mathrm{L} / \mathrm{day}$, at a HRT of 7 days, was used to study the effects of changing the temperature by $3^{\circ} \mathrm{C}$ increments. The reactor processes were reasonably stable during the increase from $37^{\circ} \mathrm{C}$ to $43^{\circ} \mathrm{C}$ and the decrease from $55^{\circ} \mathrm{C}$ to $43^{\circ} \mathrm{C}$. When the temperature was increased from $37^{\circ} \mathrm{C}$ to $46^{\circ} \mathrm{C}$, the total volatile fatty acid (TVFA) concentration and biogas production was 2,059 $\mathrm{mg}$ as acetic acid/L and $1.49 \mathrm{~L}$ of gas/L[reactor]/day at day 56, respectively. When the temperature was reduced from $55^{\circ} \mathrm{C}$ to $40^{\circ} \mathrm{C}$, the TVFA concentration and biogas production was $2,368 \mathrm{mg}$ as acetic acid/L and $2.01 \mathrm{~L}$ of gas/L[reactor]/day at day 102 , respectively. By first reducing the OLR to 4.20 g[COD]/L/day then slowly increasing the OLR back to $9.68 \mathrm{~g}[\mathrm{COD}] / \mathrm{L} / \mathrm{day}$, both reactors were restored to stable conditions at $49^{\circ} \mathrm{C}$ and $37^{\circ} \mathrm{C}$ respectively. The initial $37^{\circ} \mathrm{C}$ reactor became fully acclimatized at $55^{\circ} \mathrm{C}$ with an efficiency similar to that when operated at the initial $37^{\circ} \mathrm{C}$ whereas the $55^{\circ} \mathrm{C}$ reactor also achieved stability at $37^{\circ} \mathrm{C}$ but with a lower efficiency.

Anaerobic digestion is considered to be an effective treatment process for palm oil mill effluent (POME). This involves a consortium of microorganisms catalysing a complex series of biochemical reactions that mineralise organic matter producing methane and carbon dioxide. The key factors to successfully control the stability and efficiency of the process are reactor configurations,

*Corresponding author 
Table 1. Physico-chemical characteristics of the palm oil mill effluent.

\begin{tabular}{|c|c|c|c|c|c|c|}
\hline \multirow{3}{*}{ Parameters } & \multicolumn{4}{|c|}{$\begin{array}{c}\text { Values (mg/L) } \\
\text { This study }{ }^{c}\end{array}$} & \multirow{3}{*}{ Ahmad et al. (2003) } & \multirow{3}{*}{ Najafpour et al. (2006) } \\
\hline & $1^{\text {st }}$ Samnlo & 2nd Samnleo & $3^{\text {rd }}$ Samnlef & Ranaec & & \\
\hline & I sample & 2 samplee & o salinplei & Nanges & & \\
\hline $\mathrm{pH}^{\mathrm{a}}$ & 4.42 & 4.24 & 4.66 & $4.24-4.66$ & 4.7 & $3.8-4.4$ \\
\hline BOD & 69,215 & 62,500 & 65,427 & $62,500-69,215$ & 25,000 & $23,000-26,000$ \\
\hline COD & 112,023 & 95,465 & 100,600 & $95,465-112,023$ & 50,000 & $42,500-55,700$ \\
\hline TS & 71,993 & 75,327 & 68,854 & $68,854-75,327$ & 40,500 & - \\
\hline TSS & 47,140 & 44,680 & 46,213 & $44,680-47,140$ & 18,000 & $16,500-19,500$ \\
\hline Oil and Grease & 10,052 & 9,126 & 8,845 & $8,845-10,052$ & 4,000 & $4,900-5,700$ \\
\hline TVFA $^{b}$ & 4,226 & 4,045 & 4,335 & $4,045-4,335$ & - & - \\
\hline TKN & 1,345 & 1,305 & 1,493 & $1,305-1,493$ & 750 & $500-700^{d}$ \\
\hline $\mathrm{NH}_{3}-\mathrm{N}$ & 106 & 91 & 112 & $91-112$ & - & - \\
\hline \multicolumn{7}{|c|}{$\begin{array}{l}\text { a: no unit. } \\
\text { b: } m g \text { as acetic acid/L. } \\
\text { c: values are means of three replicates. } \\
\text { d: total nitrogen. } \\
\text { e: for study effects of varying OLRs. }\end{array}$} \\
\hline
\end{tabular}

hydraulic retention time (HRT), organic loading rates (OLR), $\mathrm{pH}$, temperature, inhibitor concentrations, concentrations of total volatile fatty acid (TVFA) and substrate composition. In order to avoid a process failure and/or low efficiency, these parameters require an investigation so that they can be maintained at or near to optimum conditions.

Generally, these anaerobic digestions are conducted at either mesophilic $\left(30-37^{\circ} \mathrm{C}\right)$ or thermophilic $\left(50-60^{\circ} \mathrm{C}\right)$ temperatures. In a palm oil mill processing system, the wastewater is discharged at relatively high temperatures

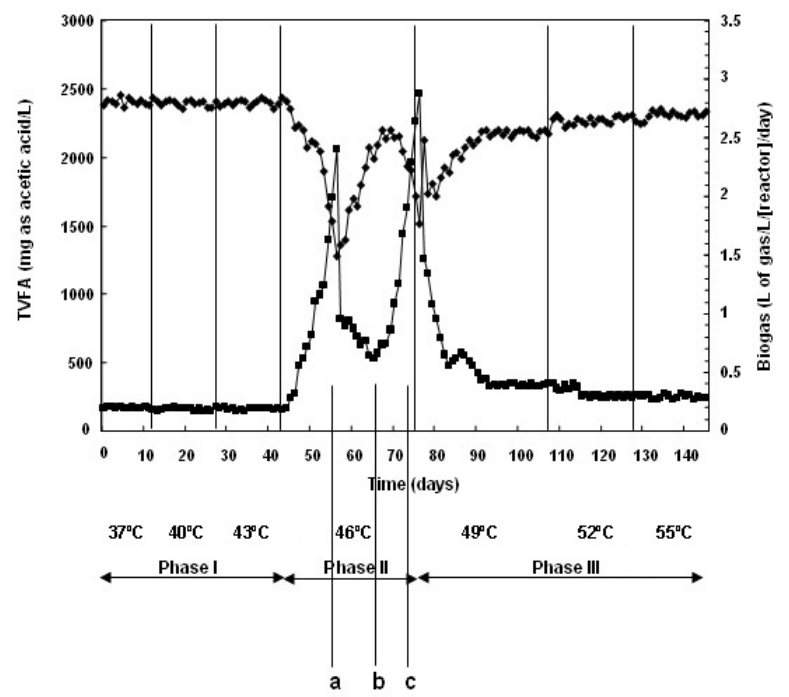

Figure 1. Variation of TVFA ( $\square$ ) and biogas production rate (४) during operation of the mesophilic reactor at different temperatures. (a) decrease in OLR from 9.68 to 4.20 $\mathrm{g}[\mathrm{COD}] / \mathrm{L} / \mathrm{day}$; (b) increase in OLR from 4.20 to 9.68 $\mathrm{g}[\mathrm{COD}] / \mathrm{L} / \mathrm{day} ;$ (c) decrease in OLR from 9.68 to 4.20 $\mathrm{g}[\mathrm{COD}] / \mathrm{L} / \mathrm{day}$ followed by a slow change from 4.20 to 9.68 g[COD]/L/day. $\left(80-90^{\circ} \mathrm{C}\right)$ (Najafpour et al. 2006), making it feasible to treat the POME at either mesophilic or thermophilic temperatures. With POME added at an OLR of 12.6 g[COD]/L/day and a HRT of 5.6 days under mesophilic temperature, Cail and Barford (1985) using a semicontinuous anaerobic reactor achieved a chemical oxygen demand (COD) removal of around $75 \%$. Using a similar configuration, of a semi-continuous anaerobic reactor, but operating with thermophilic conditions and a maximum OLR of $15.1 \mathrm{~g}[\mathrm{COD}] / \mathrm{L} /$ day and a HRT of 4.3 days they achieved a COD removal of $85 \%$, and a methane yield of $295 \mathrm{ml} / \mathrm{g}$ [COD] (Padilla and Banks, 1993). Using up flow reactors degrading synthetic wastewater of different OLRs, $\mathrm{Yu}$ et al. (2002), found that the operation at $55^{\circ} \mathrm{C}$ achieved a higher substrate degradation rate, biogas production rate, and specific rate of aqueous product formation than when operated at $37^{\circ} \mathrm{C}$. de la Rubia et al. (2002) concluded that a reactor operating at a lower $\mathrm{HRT}$ and $55^{\circ} \mathrm{C}$ produced more gas than at $35^{\circ} \mathrm{C}$ with OLR's of up to $2.19 \mathrm{~kg} \mathrm{~m}^{-3} \mathrm{~d}^{-3} \mathrm{COD}$. The digestion of a distillery waste at anaerobic digestion temperatures ranging from $35-55^{\circ} \mathrm{C}$, gave a maximum total biogas and methane yield at a digester temperature of $50^{\circ} \mathrm{C}$ (Banerjee and Biswas, 2004). According to these data, temperature is an important parameter that modifies the effectiveness of the anaerobic bacterial consortium to produce methane from organic matter.

In practice, failure to control temperature increases can result in biomass washout with a resulting accumulation of TVFAs (Lau and Fang, 1997). Any sudden change in temperature caused a lowering of COD reduction, biogas production and coincided with an accumulation of TVFAs in both a mesophilic $\left(35^{\circ} \mathrm{C}\right)$ and a thermophilic $\left(55^{\circ} \mathrm{C}\right)$ up flow anaerobic filter, treating a simulated papermill wastewater (Ahn and Forster, 2002). Daily upward temperature fluctuations affected the maximum specific methanogenic activity more severely than did a daily imposed downward temperature fluctuation (El-Mashad et 
Effect of temperature on the anaerobic digestion of palm oil mill effluent

Table 2. Performance of the mesophilic and thermophilic reactors at different OLRs under steady state conditions.

\begin{tabular}{|c|c|c|c|c|c|c|c|c|}
\hline \multirow{3}{*}{ Parameters } & \multirow{2}{*}{\multicolumn{3}{|c|}{$\begin{array}{c}\text { Mesophilic reactor }\left(37^{\circ} \mathrm{C}\right) \\
\text { HRT } 7 \text { days } \\
\text { OLRs (g[COD]/L/day) }\end{array}$}} & \multicolumn{5}{|c|}{ Thermophilic reactor $\left(55^{\circ} \mathrm{C}\right)$} \\
\hline & & & & \multicolumn{3}{|c|}{$\begin{array}{c}\text { HRT } 7 \text { days } \\
\text { OLRs (g[COD]/L/day) }\end{array}$} & \multicolumn{2}{|c|}{$\begin{array}{c}\text { HRT } 5 \text { days } \\
\text { OLRs }(g[C O D] / L / \text { day })\end{array}$} \\
\hline & 9.72 & 10.74 & 12.25 & 9.62 & 10.82 & 12.15 & 15.15 & 17.01 \\
\hline $\mathrm{pH}$ & $7.54 \pm 0.04^{b}$ & $7.44 \pm 0.03^{\mathrm{a}}$ & $7.42 \pm 0.03^{\mathrm{a}}$ & $7.80 \pm 0.03^{d}$ & $7.72 \pm 0.04^{\mathrm{c}}$ & $7.72 \pm 0.04^{c}$ & $7.72 \pm 0.03^{\mathrm{c}}$ & $7.71 \pm 0.03^{\mathrm{c}}$ \\
\hline $\begin{array}{l}\text { TVFA } \\
\text { (mg as acetic acid/L) }\end{array}$ & $172.29 \pm 8.94^{\mathrm{a}}$ & $631.86 \pm 10.15^{\mathrm{e}}$ & $815.43 \pm 12.82^{9}$ & $270.14 \pm 21.93^{b}$ & $493.29 \pm 11.39^{c}$ & $537.14 \pm 11.00^{d}$ & $734.29 \pm 19.25^{f}$ & $980.00 \pm 15.43^{h}$ \\
\hline Alkalinity (mg/L) & $3,000.00 \pm 16.98^{\mathrm{a}}$ & $3,156.57 \pm 10.71^{c}$ & $3,157.14 \pm 20.04^{c}$ & $3,126.79 \pm 22.92^{b}$ & $3,144.64 \pm 34.92^{\mathrm{bc}}$ & $3,150.21 \pm 32.27^{c}$ & $3,451.79 \pm 21.29^{\mathrm{e}}$ & $3,227.68 \pm 26.93^{d}$ \\
\hline TVFA/alkalinity & $0.06 \pm 0.00^{\mathrm{a}}$ & $0.20 \pm 0.00^{\mathrm{e}}$ & $0.26 \pm 0.00^{9}$ & $0.09 \pm 0.01^{b}$ & $0.16 \pm 0.01^{\mathrm{c}}$ & $0.17 \pm 0.00^{d}$ & $0.21 \pm 0.01^{f}$ & $0.30 \pm 0.01^{h}$ \\
\hline $\begin{array}{l}\begin{array}{l}\text { Biogas production } \\
\text { (L of gas/L[reactor]/day) }\end{array} \\
\end{array}$ & $2.81 \pm 0.04^{b}$ & $3.36 \pm 0.03^{d}$ & $3.73 \pm 0.05^{\mathrm{e}}$ & $2.70 \pm 0.05^{\mathrm{a}}$ & $3.30 \pm 0.02^{\mathrm{c}}$ & $3.81 \pm 0.04^{\dagger}$ & $4.06 \pm 0.05^{\mathrm{g}}$ & $4.66 \pm 0.03^{h}$ \\
\hline Gas yield (L/g[COD]) & $0.66 \pm 0.01^{b}$ & $0.71 \pm 0.01^{\mathrm{e}}$ & $0.69 \pm 0.01^{\mathrm{c}}$ & $0.66 \pm 0.01^{b}$ & $0.70 \pm 0.01^{d}$ & $0.70 \pm 0.01^{d}$ & $0.63 \pm 0.0^{\mathrm{a}}$ & $0.62 \pm 0.01^{\mathrm{a}}$ \\
\hline $\begin{array}{l}\text { Methane production } \\
\text { (L/L[reactor]/day) }\end{array}$ & $1.96 \pm 0.03^{b}$ & $2.39 \pm 0.05^{d}$ & $2.65 \pm 0.04^{e}$ & $1.91 \pm 0.04^{\mathrm{a}}$ & $2.31 \pm 0.03^{c}$ & $2.68 \pm 0.03^{f}$ & $2.82 \pm 0.06^{9}$ & $3.24 \pm 0.04^{h}$ \\
\hline Methane yield (L/g[COD]) & $0.46 \pm 0.01^{b}$ & $0.51 \pm 0.01^{\mathrm{e}}$ & $0.49 \pm 0.01^{d}$ & $0.47 \pm 0.01^{\mathrm{c}}$ & $0.49 \pm 0.01^{d}$ & $0.49 \pm 0.01^{d}$ & $0.44 \pm 0.01^{\mathrm{a}}$ & $0.44 \pm 0.05^{\mathrm{a}}$ \\
\hline COD reduction (\%) & $69.89 \pm 0.65^{c}$ & $70.44 \pm 0.33^{d}$ & $71.10 \pm 0.31^{\mathrm{e}}$ & $67.73 \pm 0.63^{\mathrm{a}}$ & $69.88 \pm 0.15^{c}$ & $72.16 \pm 0.33^{f}$ & $68.20 \pm 0.24^{\mathrm{b}}$ & $70.32 \pm 0.30^{d}$ \\
\hline
\end{tabular}

Values are averages \pm SD of three determinations taken over fourteen days during steady state conditions.

Averages followed by the different letters in the same row are statistically different at $95 \%$ level by Duncan's multiple Range test.

al. 2004). Because of this information, together with the high temperature of POME and the variation of the POME wastewater volumes during high and low seasons, we have investigated the performance of a continuous stirred tank reactor (CSTR) operating in a steady state at both $37^{\circ} \mathrm{C}$ and $55^{\circ} \mathrm{C}$ and the effects of variations of OLRs and

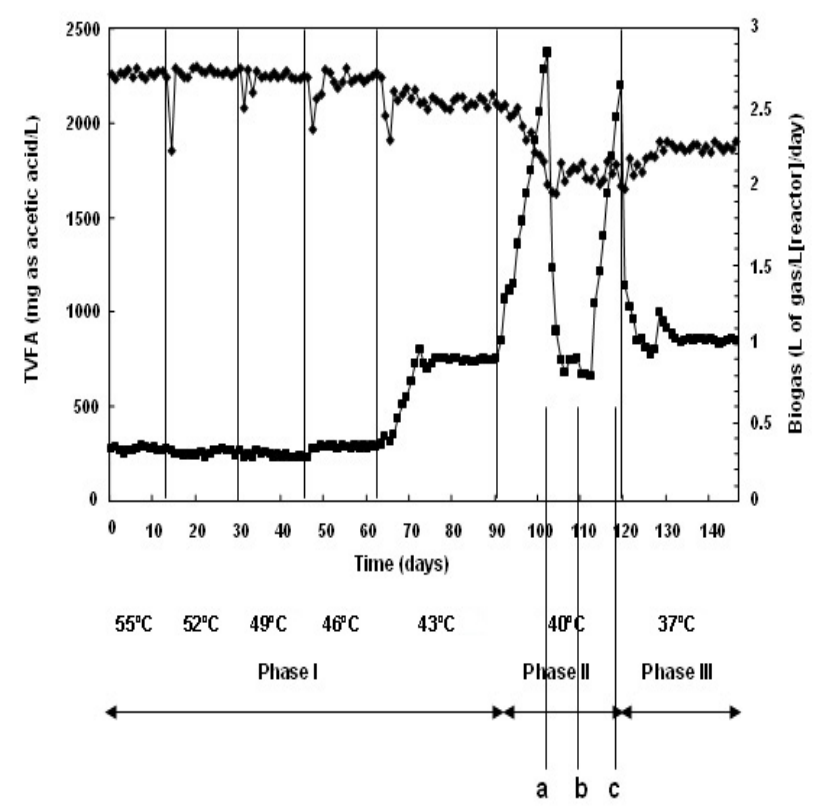

Figure 2. Variation of TVFA ( $\square$ ) and biogas production rate $(\diamond)$ during operation of the thermophilic reactor at different temperatures. (a)decrease in OLR from 9.68 to $4.20 \mathrm{~g}[\mathrm{COD}] / \mathrm{L} /$ day; (b) increase in OLR from 4.20 to 9.68 $\mathrm{g}[\mathrm{COD}] / \mathrm{L} / \mathrm{day} ;$ (c) decrease in OLR from 9.68 to 4.20 $\mathrm{g}[\mathrm{COD}] / \mathrm{L} / \mathrm{day}$ followed by a slow change from 4.20 to 9.68 $\mathrm{g}[\mathrm{COD}] / \mathrm{L} / \mathrm{day}$. temperatures shifts on the performance of reactors operating at a relatively low OLR level.

\section{MATERIALS AND METHODS}

\section{POME characterization}

Fresh POME was collected monthly from a conventional palm oil mill factory located in Surat-thani province, Thailand. After the determination of its physico-chemical properties, the wastewater was stored in a sealed container and kept in a cold room at $4^{\circ} \mathrm{C}$ until used.

\section{Equipment}

The CSTR reactors used have a $12 \mathrm{~cm}$ internal diameter with a height of $27 \mathrm{~cm}$. The reactors were maintained at the constant desired temperature using hot water circulation around the reactors. Feed was pumped semi-continuously through the feeding hole, (5 $\mathrm{mm}$ in diameter), near the bottom by means of a peristaltic pump. Samples were withdrawn from sampling holes (5 $\mathrm{mm}$ in diameter) located 1,8 and $15 \mathrm{~cm}$ from the bottom. Mixing was achieved by stirring the medium at $70 \mathrm{rpm}$ with a magnetic bar $(0.8 \times 5$ $\mathrm{cm})$.

\section{Inoculum}

A conventional POME treatment pond with an area of 110 $\mathrm{x} 191 \mathrm{~m}^{2}$, and $4 \mathrm{~m}$ in depth was fed with an OLR of 0.5-1.5 $\mathrm{kg}[\mathrm{COD}] / \mathrm{L} /$ day with a residence time of 20-30 days. The inoculum sludge for seeding the reactors was brought from this site and adapted with diluted POME (POME:tap water $=1: 4 \mathrm{v} / \mathrm{v}$ ) for 7-10 days at the desired temperature, and then 
Table 3. Division of the process performance based on the effect of temperature shifts during operation of the reactors.

\begin{tabular}{|c|c|c|c|}
\hline \multirow{2}{*}{ Reactor } & \multicolumn{3}{|c|}{ Temperature shifts $\left.{ }^{\circ} \mathrm{C}\right)$} \\
\cline { 2 - 4 } & Phase I & Phase II & Phase III \\
\hline Mesophilic & $37-43$ & 46 & $49-55$ \\
\hline Thermophilic & $55-43$ & 40 & 37 \\
\hline
\end{tabular}

inoculated into the digesters with an initial total solid (TS) and volatile suspended solid (VSS) of around 35-37 and 15$16 \mathrm{~g} / \mathrm{L}$, respectively.

\section{Effects of varying OLRs on the performance of the reactors}

Two CSTRs each with a 1.6-L working volume were fed with acclimatized POME. One reactor was controlled at a temperature of $37^{\circ} \mathrm{C}$ (mesophilic reactor) and the other at $55^{\circ} \mathrm{C}$ (thermophilic reactor). The COD of the POME was adjusted to the desired value with tap water. The various OLRs were achieved at a HRT of 7 days for the $37^{\circ} \mathrm{C}$ reactor and 5 days for the $55^{\circ} \mathrm{C}$ reactor. The physicochemical characteristics of the effluent used in this section are shown in Table 1 ( $2^{\text {nd }}$ sample).

\section{Effect of temperature shifts on the performance of the reactors}

Temperatures were changed in both reactors while being operated at a HRT of 7 days (OLR $9.68 \mathrm{~g}[\mathrm{COD}] / \mathrm{L} /$ day). The temperature of the $37^{\circ} \mathrm{C}$ reactor was increased up to $55^{\circ} \mathrm{C}$ gradually by $3^{\circ} \mathrm{C}$ at a time, while the temperature of the $55^{\circ} \mathrm{C}$ reactor was decreased until it reached $37^{\circ} \mathrm{C}$ again by $3^{\circ} \mathrm{C}$ at a time. After each temperature change the reactor was left at the new temperature until a steady state was achieved. This took at least 2 weeks and sometimes longer before the next temperature shift. The $37^{\circ} \mathrm{C}$ reactor was operated at $37,40,43,46,49,52$ and $55^{\circ} \mathrm{C}$ for $14,15,15$, 33, 31, 22 and 16 days, respectively. The $55^{\circ} \mathrm{C}$ reactor was operated at $55,52,49,46,43,40$ and $37^{\circ} \mathrm{C}$ for $14,17,16$, 17, 27, 29 and 27 days, respectively. After the $37^{\circ} \mathrm{C}$ and $55^{\circ} \mathrm{C}$ reactors were operated at $46^{\circ} \mathrm{C}$ and $40^{\circ} \mathrm{C}$, respectively a major loss of steady state as indicated from the increase in TVFA and the decreasing biogas production. The OLR was reduced to try to stabilize the system, then, gradually increased to the normal working OLR to achieve a new steady state. Physico-chemical characteristics of the effluent used in this section are shown in Table $1\left(3^{\text {rd }}\right.$ sample).

It was considered that a steady-state had been achieved when the levels of TVFA, COD removal, biogas production rate and composition varied by less than $3 \%$ on three consecutive days (Borja et al. 1996). The values shown in Table 2, Table 4 and Table 5 were the average values obtained after measuring the given parameters for a 2 week period of that steady-state.

\section{Chemical analyses}

Gas volume was measured by using a displacement of acidified water ( $\mathrm{pH} 2-3$ ) and methane by $\mathrm{KOH}$ solution displacement in a serum bottle, as described previously (Ergüder et al. 2001). Alkalinity was measured by the direct titration method (Jenkins et al. 1983). Biochemical oxygen demand (BOD), COD, TVFA, pH, TS, total suspended solid (TSS), total Kjeldahl nitrogen (TKN), $\mathrm{NH}_{3}-\mathrm{N}$ and oil and grease were determined in triplicate according to standard methods (Clescerl et al. 1998).

\section{Data analysis}

Means \pm SD of pH, TVFA, alkalinity, TVFA/alkalinity, biogas and methane productions, biogas and methane yields and COD removal were calculated from data to be collected from the reactors operated under steady state (14 days) under variation of OLRs and temperature shifts. These data were subjected to statistical analyses using SPSS program version 10. Completely randomized design was employed for analysis of variance (ANOVA). The difference between means was evaluated by using Duncan's multiple range test. $P<0.05$ was considered as significant.

\section{RESULTS AND DISCUSSION}

\section{Characteristics of POME}

The physico-chemical parameters of POME used in this study (Table 1 ) were very different from those previously reported (Ahmad et al. 2003; Najafpour et al. 2006). This is due to a change in the mill operation. For example, a much smaller water volume was used to remove the majority of the suspended material from the lipids. This allowed for a considerable reduction in the amount of wastewater generated in the process, and consequently a higher content of organic and inorganic matter. Since the COD/BOD ratio of POME is about 1.56 a good possibility exists that the organic matter is biodegradable (Raj and Anjaneyulu, 2005). The main recalcitrant organic material found in POME was lignocellulose (Oswal et al. 2002). The large amounts of identified biodegradable components were oil and grease, which can be hydrolyzed by microorganisms to fatty acids. Some of these fatty acids are potential substrates for methane production which does allow a favourable economic outcome (Angelidaki et al. 1990). In contrast, the lipid-rich waste contains long chain fatty acids, 
Effect of temperature on the anaerobic digestion of palm oil mill effluent

Table 4. Performance of the mesophilic reactor at different operating temperatures under steady-state conditions.

\begin{tabular}{|c|c|c|c|c|c|c|}
\hline \multirow{3}{*}{ Parameters } & \multicolumn{6}{|c|}{ Temperature $\left({ }^{\circ} \mathrm{C}\right)$} \\
\hline & \multicolumn{3}{|c|}{ Phase I } & \multicolumn{3}{|c|}{ Phase III } \\
\hline & 37 & 40 & 43 & 49 & 52 & 55 \\
\hline $\mathrm{pH}$ & $7.55 \pm 0.05^{a}$ & $7.57 \pm 0.03^{a}$ & $7.61 \pm 0.02^{b}$ & $7.68 \pm 0.07^{c}$ & $7.73 \pm 0.04^{d}$ & $7.80 \pm 0.03^{\mathrm{e}}$ \\
\hline $\begin{array}{l}\text { TVFA (mg as acetic } \\
\text { acid/L) }\end{array}$ & $166.64 \pm 7.44^{\mathrm{a}}$ & $162.43 \pm 8.31^{\mathrm{a}}$ & $160.71 \pm 6.73^{\mathrm{a}}$ & $338.71 \pm 14.87^{c}$ & $253.07 \pm 7.32^{\mathrm{b}}$ & $245.07 \pm 15.32^{b}$ \\
\hline Alkalinity (mg/L) & $3,051 \cdot 00 \pm 33.70^{b}$ & $3,053.79 \pm 32.74^{b}$ & $3,061.71 \pm 31.58^{b}$ & $2,981 \cdot 43 \pm 31 \cdot 31^{\mathrm{a}}$ & $2,974.36 \pm 23.82^{a}$ & $2,984.14 \pm 28.34^{a}$ \\
\hline TVFA/Alkalinity & $0.06 \pm 0.00^{b}$ & $0.05 \pm 0.00^{\mathrm{a}}$ & $0.05 \pm 0.00^{a}$ & $0.11 \pm 0.01^{d}$ & $0.08 \pm 0.00^{c}$ & $0.08 \pm 0.00^{c}$ \\
\hline $\begin{array}{l}\text { Biogas production } \\
\text { (L of } \\
\text { gas/L[reactor]/day) }\end{array}$ & $2.81 \pm 0.03^{d}$ & $2.79 \pm 0.02^{d}$ & $2.80 \pm 0.03^{d}$ & $2.54 \pm 0.02^{\mathrm{a}}$ & $2.65 \pm 0.03^{b}$ & $2.70 \pm 0.02^{c}$ \\
\hline Gas yield (L/g[COD]) & $0.66 \pm 0.01^{d}$ & $0.65 \pm 0.01^{c}$ & $0.66 \pm 0.01^{d}$ & $0.61 \pm 0.01^{a}$ & $0.64 \pm 0.01^{b}$ & $0.66 \pm 0.01^{d}$ \\
\hline $\begin{array}{l}\text { Methane production } \\
\text { (L/L[reactor]/day) }\end{array}$ & $1.97 \pm 0.02^{c}$ & $1.97 \pm 0.02^{\mathrm{c}}$ & $1.98 \pm 0.02^{\mathrm{c}}$ & $1.72 \pm 0.16^{a}$ & $1.86 \pm 0.02^{b}$ & $1.91 \pm 0.03^{b}$ \\
\hline $\begin{array}{l}\text { Methane yield } \\
(\mathrm{L} / \mathrm{g}[\mathrm{COD}])\end{array}$ & $0.46 \pm 0.01^{c}$ & $0.46 \pm 0.01^{c}$ & $0.46 \pm 0.1^{c}$ & $0.42 \pm 0.01^{a}$ & $0.45 \pm 0.00^{\mathrm{b}}$ & $0.47 \pm 0.01^{d}$ \\
\hline COD reduction (\%) & $70.34 \pm 0.39^{d}$ & $70.76 \pm 0.02^{e}$ & $70.85 \pm 0.45^{\mathrm{e}}$ & $69.08 \pm 0.92^{\mathrm{c}}$ & $68.31 \pm 0.36^{b}$ & $67.62 \pm 0.40^{\mathrm{a}}$ \\
\hline
\end{tabular}

Averages followed by the different letters in the same row are statistically different at $95 \%$ level by Duncan's multiple Range test.

especially palmitate (higher than $50 \mathrm{mg} / \mathrm{g}_{\text {dry }}$ weight ) and oleate (higher than $200 \mathrm{mg} / \mathrm{L}$ ), that were hydrolysis products of fat \& oil and these have been reported to inhibit bacterial growth and methane formation (Cirne et al. 2007). The high amounts of TS and TSS in the POME comes from insoluble organic substances being washed out during the production process. It has to be emphasized that the upflow anaerobic sludge blanket process appears to be particularly sensitive to the loading of solids. Thus Borja et al. (1996) used a two-stage up-flow anaerobic sludge blanket for treating POME. As soon as the suspended solids concentration of POME in the acidogenic reactor was increased to $10.8 \mathrm{~g} / \mathrm{L}$, an accumulation of organic solids in the reactor was observed.

\section{Effects of varying OLRs on the performance of the reactors}

Reactor performance is usually evaluated in terms of stability and efficiency of the process estimated through the measurement of $\mathrm{pH}$, TVFA and alkalinity, COD removal, gas production and methane production (Table 2). For the $37^{\circ} \mathrm{C}$ reactor, as the OLR was increased from 9.72 to 12.25 $\mathrm{g}[\mathrm{COD}] / \mathrm{L} /$ day, the $\mathrm{pH}$ was significantly $[p<0.05]$ reduced from 7.54 to 7.42 with a significant $[p<0.05]$ increase of TVFA from 172.29 to $815.43 \mathrm{mg}$ acetic acid/L. At an OLR of $12.25 \mathrm{~g}[\mathrm{COD}] / \mathrm{L} /$ day, the ratio of TVFA/alkalinity was 0.26 . Zinatizadeh et al. (2006) demonstrated that treating POME in an up-flow anaerobic sludge fixed film (UASFF) reactor at $38^{\circ} \mathrm{C}$, with OLRs of $14.49,21.31,26.21$ and $34.73 \mathrm{~g}[\mathrm{COD}] / \mathrm{L} /$ day with a HRT of 1 day, the TVFA concentration increased to 93.5, 165.1, 365.2 and 843.2 $\mathrm{mg} / \mathrm{L}$ respectively. This implied an increasing unbalance between acid formation and methane production in the system. However under the conditions of this experiment, the $\mathrm{pH}$ of the effluent (7.42) was in the optimal range (6.97.9) for anaerobic digestion, far from a pH of 5.3, known to decrease methane concentration by about 59\% (Björnsson et al. 2000). Also Song et al. (2004) reported that the buffering capacity was sufficient when the TVFA/alkalinity was maintained below 0.4 .

The $\mathrm{pH}$ values in the $55^{\circ} \mathrm{C}$ reactor were significantly $[p<$ 0.05] higher than those in the $37^{\circ} \mathrm{C}$ reactor at all OLRs tested (Table 2). However, the ranges of $\mathrm{pH}$ values were all within the optimal $\mathrm{pH}$ values for methane production (Wheatley, 1990). At an HRT of 7 days and an OLR increasing from 9.62 to $12.15 \mathrm{~g}[\mathrm{COD}] / \mathrm{L} /$ day, the levels of TVFAs in the $55^{\circ} \mathrm{C}$ reactor increased from 270.14 to 537.14 $\mathrm{mg}$ acetic acid/L, with the TVFA/alkalinity ratio changing only between $0.09-0.17$ compared to a change from 0.06 to 0.26 at $37^{\circ} \mathrm{C}$ using the same loadings and HRT. These results imply that at the same level of OLR, the process in the $55^{\circ} \mathrm{C}$ reactor was more stable than in the $37^{\circ} \mathrm{C}$ reactor. Increasing the OLR in the $55^{\circ} \mathrm{C}$ reactor to 17.01 $\mathrm{g}[\mathrm{COD}] / \mathrm{L} /$ day with an HRT of 5 days, caused a significant $[p<0.05]$ increase of the TVFA/alkalinity ratio to 0.30 and therefore this system was under severe stress.

The efficiency of COD reduction was between 69.89$71.10 \%$ at OLRs from $9.72-12.25 \mathrm{~g}[\mathrm{COD}] / \mathrm{L} /$ day for the $37^{\circ} \mathrm{C}$ reactor with a methane yield of $0.46-0.51 \mathrm{~L} / \mathrm{g}$ [COD] and methane production was 1.96-2.65 L/L[reactor]/day. The $55^{\circ} \mathrm{C}$ reactor gave a COD reduction of between 67.73$72.16 \%$, a methane yield of $0.44-0.49 \mathrm{~L} / \mathrm{g}[\mathrm{COD}]$ and 
methane production was 1.91-3.24 L/L[reactor]/day. The biogas and methane productions of both reactors significantly $[p<0.05]$ increased with an increasing OLR (Table 2).

As far as the performance of the process is concerned, the $37^{\circ} \mathrm{C}$ reactor ran successfully at the maximum OLR tested (12.25 g[COD]/L/day) and an HRT of 7 days. At an HRT of 5 days, the $55^{\circ} \mathrm{C}$ reactor also ran successfully at the maximum OLR tested (17.01 g[COD]/L/day). In both these cases, although the TVFA levels were significantly $[p<$ 0.05] raised to 815.43 and $980.00 \mathrm{mg}$ acetic acid/L, respectively; the reduction of \% COD was still high and a significant increase in the production of biogas and methane occurred. This work showed that the capital cost of the anaerobic digester could be lowered by operating the reactor at a thermophilic temperature. Borja and Banks (1995) reported that changing the type of reactor also affected OLRs; for example, using an anaerobic filter or a fluidized-bed reactor or an UASFF reactor, each had its own characteristics (Zinatizadeh et al. 2006). However, these reactor types did not work well with wastewater of high solid content (Björnsson et al. 1997). Thermophilic digestion is now becoming of great interest for sewage sludge treatment due to its potential for a better reduction of potential pathogens compared to that using mesophilic digestion (Boušková et al. 2005). Since POME has an initial temperature of $80-90^{\circ} \mathrm{C}$ (Najafpour et al. 2006), operating the reactor under thermophilic conditions would be more economical than under mesophilic conditions in terms of the ability to use a smaller digester and obtaining a better methane production rate (Table 2).

\section{Effect of temperature shifts on the performance of the reactors}

The responses of the performance of the processes to changes in temperature were investigated in the 37 and $55^{\circ} \mathrm{C}$ reactors at an HRT of 7 days and an OLR of 9.68 $\mathrm{g}[\mathrm{COD}] / \mathrm{L} /$ day. The performance of both reactors was divided into three phases (Table 3).

Phase I. After changing the temperature, only minor changes in the operating processes were observed in phase I with either reactor. The performance of the mesophilic reactor is shown in Figure 1 and the thermophilic reactor in Figure 2. The results illustrate that the performanceof the $37^{\circ} \mathrm{C}$ reactor changed insignificantly in terms of any of the measured parameters as the temperature was raised to $40^{\circ} \mathrm{C}$ and $43^{\circ} \mathrm{C}$. These results were confirmed by statistic tests which showed that the levels of TVFA, alkalinity, biogas and methane productions and methane yield did not significantly $[p<0.05]$ change (Table 4 ). For example, the TVFA levels ranged from 160.71-166.64 $\mathrm{mg}$ as acetic $\mathrm{acid} / \mathrm{L}$ and biogas production was 2.79-2.81 $\mathrm{L}$ of gas/L[reactor]/day (Table 4 ). The $55^{\circ} \mathrm{C}$ reactor, operated over the reducing temperature range of $52^{\circ} \mathrm{C}, 49^{\circ} \mathrm{C}$ and $46^{\circ} \mathrm{C}$ also produced only minor changes in efficiency. The biogas production varied from 2.67-2.72 L of gas/L[reactor]/day and methane production ranged from 1.86-1.89 L/L[reactor]/day. However when the temperature was reduced from 46 to $43^{\circ} \mathrm{C}$ the efficiency of the process became lower with a significant $[p<0.05]$ drop in methane (1.77 L/L[reactor]/day) and biogas productions $(2.53 \mathrm{~L}$ of gas/L[reactor]/day) (Table 5). The process became unstable with a significant increase in TVFA levels $(746.14 \mathrm{mg}$ as acetic acid/L). Moreover, at each $3^{\circ} \mathrm{C}$ temperature shift

from $55^{\circ} \mathrm{C}$ to $52^{\circ} \mathrm{C}, 49^{\circ} \mathrm{C}, 46^{\circ} \mathrm{C}$ and $43^{\circ} \mathrm{C}$ there was a rapid initial drop in biogas production rate that was quickly reversed over a few days (Figure 2). These results indicated that the $55^{\circ} \mathrm{C}$ reactor was quite sensitive to the temperature disturbances, probably due to induction of a temporary unbalance of the microorganisms in the reactor. Speece (1996) reported that methanogens are more sensitive to

Table 5. Performance of the thermophilic reactor at different operating temperatures under steady-state conditions.

\begin{tabular}{|c|c|c|c|c|c|c|}
\hline \multirow{3}{*}{ Parameters } & \multicolumn{6}{|c|}{ Temperature $\left({ }^{\circ} \mathrm{C}\right)$} \\
\hline & \multicolumn{5}{|c|}{ Phase I } & \multirow{2}{*}{$\begin{array}{c}\text { Phase III } \\
37\end{array}$} \\
\hline & 55 & 52 & 49 & 46 & 43 & \\
\hline $\mathrm{pH}$ & $7.78 \pm 0.04^{c}$ & $7.78 \pm 0.04^{c}$ & $7.76 \pm 0.04^{c}$ & $7.60 \pm 0.13^{a}$ & $7.69 \pm 0.13^{b}$ & $7.57 \pm 0.04^{a}$ \\
\hline TVFA (mg as acetic acid/L) & $274.86 \pm 8.99^{c}$ & $256.43 \pm 14.64^{b}$ & $239.71 \pm 12.44^{\mathrm{a}}$ & $284.29 \pm 6.30^{d}$ & $746.14 \pm 6.05^{\mathrm{e}}$ & $851.29 \pm 7.96^{\dagger}$ \\
\hline Alkalinity (mg/L) & $3,122 \cdot 32 \pm 23 \cdot 6^{b c}$ & $3,114.29 \pm 16.16^{b c}$ & $3,117.86 \pm 34.22^{b c}$ & $3,134.82 \pm 25.09^{c}$ & $3,058.93 \pm 27.49^{a}$ & $3,106.79 \pm 21.15^{t}$ \\
\hline TVFA/Alkalinity & $0.09 \pm 0.00^{c}$ & $0.08 \pm 0.00 b$ & $0.07 \pm 0.00^{a}$ & $0.09 \pm 0.00^{c}$ & $0.24 \pm 0.00^{d}$ & $0.27 \pm 0.00 \mathrm{e}$ \\
\hline $\begin{array}{l}\text { Biogas production (L of } \\
\text { gas/L[reactor]/day) }\end{array}$ & $2.71 \pm 0.02^{\mathrm{d}} \mathrm{e}$ & $2.72 \pm 0.02^{\mathrm{e}}$ & $2.69 \pm 0.03^{\mathrm{cd}}$ & $2.67 \pm 0.06^{c}$ & $2.53 \pm 0.03^{b}$ & $2.24 \pm 0.02^{\mathrm{a}}$ \\
\hline Gas yield (L/g[COD]) & $0.65 \pm 0.01^{\mathrm{c}}$ & $0.66 \pm 0.01^{\mathrm{d}}$ & $0.65 \pm 0.01^{c}$ & $0.65 \pm 0.01^{\mathrm{c}}$ & $0.62 \pm 0.01^{b}$ & $0.56 \pm 0.01^{a}$ \\
\hline $\begin{array}{l}\text { Methane production } \\
\text { (L/L[reactor]/day) }\end{array}$ & $1.86 \pm 0.02^{c}$ & $1.89 \pm 0.02^{d}$ & $1.89 \pm 0.02^{d}$ & $1.89 \pm 0.04^{d}$ & $1.77 \pm 0.02^{b}$ & $1.55 \pm 0.02^{\mathrm{a}}$ \\
\hline Methane yield (L/g[COD]) & $0.44 \pm 0.01^{\mathrm{c}}$ & $0.46 \pm 0.01^{d}$ & $0.46 \pm 0.01 d$ & $0.46 \pm 0.01^{d}$ & $0.43 \pm 0.01^{b}$ & $0.39 \pm 0.00^{a}$ \\
\hline COD reduction (\%) & $69.27 \pm 0.06^{d}$ & $68.26 \pm 0.48^{c}$ & $68.54 \pm 0.45^{c}$ & $67.80 \pm 0.43^{b}$ & $67.65 \pm 0.69^{b}$ & $65.71 \pm 0.32^{a}$ \\
\hline
\end{tabular}

Values are averages \pm SD of three determinations taken over fourteen days during steady state conditions.

Averages followed by the different letters in the same row are statistically different at $95 \%$ level by Duncan's multiple Range test. 
temperature changes than acidogens. It maybe that the rate at which the methanogens converted the fatty acids to methane was initially reduced far more than the rate at which the acidogens produced acids.

As shown in Table 5, the $\mathrm{pH}$ in the $55^{\circ} \mathrm{C}$ reactor (operating in the steady state at $55,52,49,46$ and with slightly changed parameters at $43^{\circ} \mathrm{C}$ ) were in the range of 7.60 7.78. The higher $\mathrm{pH}$ levels (7.78-7.76) occurring in the 55$49^{\circ} \mathrm{C}$ reactor were in agreement with results from a previous study (de la Rubia et al. 2002). The alkalinity levels of the $55^{\circ} \mathrm{C}$ reactor were also higher than those of the $37^{\circ} \mathrm{C}$ reactor (Table 4), thus an increase of TVFA levels in the $55^{\circ} \mathrm{C}$ reactor was compensated by an increased alkalinity. This allowed neutralization of the TVFA and prevented a $\mathrm{pH}$ drop (Borja et al. 1995). In addition, the process is considered to be operating effectively as TVFA/alkalinity ratios between 0.05-0.06 (Table 4) and 0.08-0.09 (Table 5), are still some way from the failure limit of 0.3-0.4 (Rittmann and McCarty, 2001).

In addition, temperature shifts of the $55^{\circ} \mathrm{C}$ reactor to 52,49 and $46^{\circ} \mathrm{C}$ and for the $37^{\circ} \mathrm{C}$ to 40 and $43^{\circ} \mathrm{C}$ had no detrimental effect on reactor performance with the COD removal efficiencies remaining about $68 \%$ in both reactors. Also the methane production and yields did not vary significantly at these different temperatures. It seems therefore that temperature shifts do not directly affect the gas composition (Table 4 and Table 5). From these results, we can conclude that the microorganisms present in these reactors must have a tolerance for a fairly wide range of temperatures. This may be attributed to the presence of thermotolerant organisms that can quickly adapt to any newly imposed temperature change. Chen (1983) reported that the development of a bacterial community involved in the degradative system could be related to the percentage of mesophilic and thermophilic bacteria in the initial sludge. Iranpour et al. (2002) have also suggested that an upward temperature shift may lead to the development of a culture dominated by thermotolerant mesophilic organism rather than true thermophiles.

Moreover, both reactors could be operated successfully at $43^{\circ} \mathrm{C}$, which is considered to be the optimal change-over temperature from mesophiles to thermophiles.

Phase II. In phase II a temperature shift of $3^{\circ} \mathrm{C}$ did cause a loss of stability and a change in the performance of the reactors. This was clearly observed when the $37^{\circ} \mathrm{C}$ reactor temperature was raised from $43^{\circ} \mathrm{C}$ to $46^{\circ} \mathrm{C}$ and for the $55^{\circ} \mathrm{C}$ reactor, the temperature was lowered from $43^{\circ} \mathrm{C}$ to $40^{\circ} \mathrm{C}$. Process instability was observed as TVFA concentrations rapidly increased from 156 to 2,059 over the first 13 days after the change from $43^{\circ} \mathrm{C}$ to $46^{\circ} \mathrm{C}$ and from 750 to 2,368 over the first 12 days from $43^{\circ} \mathrm{C}$ to $40^{\circ} \mathrm{C}$. This indicated a significant change in the balance among the microbial groups involved in the system. It is unlikely that such temperature changes occur in the normal operating environment of the methanogenic sludge. During these periods of operation the performance of the processes were poor with the biogas production rates dropping to a minimum value $\left(1.49 \mathrm{~L}\right.$ of gas/L[reactor]/day for the $37^{\circ} \mathrm{C}$ reactor and $2.01 \mathrm{~L}$ of gas/L[reactor]/day for the $55^{\circ} \mathrm{C}$ reactor). Perhaps a consortium adapted to operate at $37^{\circ} \mathrm{C}$ ceases to function effectively at $46^{\circ} \mathrm{C}$ while a consortium adapted to operate at $55^{\circ} \mathrm{C}$ ceases to operate effectively at $40^{\circ} \mathrm{C}$. Griffin et al. (1998) reported that the methanogenic bacteria are the limiting microbial group during the period of adaptation to thermophilic conditions. Boušková et al. (2005) also observed a strong disturbance when the reactor temperature was adjusted from $42^{\circ} \mathrm{C}$ to $47^{\circ} \mathrm{C}$. In particular, the optimal growth rate of any particular bacterial strain occurs over a limited temperature range. Once this temperature range is exceeded, growth rate drops off rapidly due to denaturation of key proteins (Rittmann and McCarty, 2001). The loss of function of any one of the microbes involved in the degradative system will alter the overall process.

Since, the unstable conditions of both reactors were most clearly shown in the changes in TVFA levels, the OLR of the reactors was lowered in an attempt to restore an effective process. Decreasing the OLR from 9.68 to 4.20 $\mathrm{g}[\mathrm{COD}] / \mathrm{L} /$ day during the transition period resulted in a significant drop in the TVFA levels in both reactors to 532 $\mathrm{mg}$ as acetic acid/L ( $37^{\circ} \mathrm{C}$ reactor) and $665 \mathrm{mg}$ as acetic $\mathrm{acid} / \mathrm{L}\left(55^{\circ} \mathrm{C}\right.$ reactor) and the process stabilized. However, when the OLRs were again increased to 9.68 $\mathrm{g}[\mathrm{COD}] / \mathrm{L} /$ day between days $67-76\left(37^{\circ} \mathrm{C}\right.$ reactor $)$ and days $111-119\left(55^{\circ} \mathrm{C}\right.$ reactor) the performance was again reduced as shown by a marked continued rise in TVFA to 2,459 for the $37^{\circ} \mathrm{C}$ and 2,198 for the $55^{\circ} \mathrm{C}$ reactor and a concomitant decline in biogas production.

The responses of $\mathrm{pH}$, alkalinity, reduction of COD, and methane content were somewhat delayed after the instability developed (data not shown). However, the increased TVFA was not accompanied by a corresponding increase in alkalinity so the $\mathrm{pH}$ fell during this period.

Phase III. In an attempt to recover the reactor performance after the onset of the unstable transient conditions in phase II, both reactors were fed with a decreased OLR (4.20) followed by a gradual increase (to 9.68) over a period of time to allow for any adaptation of the microbial populations. This readjustment occurred during days 77-93 for the $37^{\circ} \mathrm{C}$ reactor and from $120-132$ for the $55^{\circ} \mathrm{C}$ reactor and during this time the temperature was altered again to $49^{\circ} \mathrm{C}$ and $37^{\circ} \mathrm{C}$ for the $37^{\circ} \mathrm{C}$ and $55^{\circ} \mathrm{C}$ reactors, respectively. The $37^{\circ} \mathrm{C}$ reactor became stabilized again at $49^{\circ} \mathrm{C}$ after about day 93 with a substantial drop in TVFA levels to $338.71 \mathrm{mg}$ (as acetic acid/L). The $55^{\circ} \mathrm{C}$ became stabilized at $37^{\circ} \mathrm{C}$ at about day 130 with a TVFA level of $851.29 \mathrm{mg}$ as acetic acid/L. Both these new TVFA levels were significantly $[p<0.05]$ higher than those of the steady state in phase I, especially with the $55^{\circ} \mathrm{C}$ reactor (Table 4 and Table 5). This data revealed that the bacterial consortium and in particular the methanogens, in both digesters were 
able to adapt to new conditions of temperature and OLR and achieve a new steady-state. Once methanogenesis had recovered, a relatively stable environmental condition could be maintained in the system.

The adaptation of the mesophilic population operating at $37^{\circ} \mathrm{C}$ to thermophilic conditions at $55^{\circ} \mathrm{C}$ led to a stable process that is significantly different from that previously found at $37^{\circ} \mathrm{C}$ (Table 4) and was different from the performance of the initial $55^{\circ} \mathrm{C}$ reactor (Table 5). This new process allows for a conversion of organic matter into the final end-product without accumulation of intermediates. This could be attributed to the rapid development of thermophilic methanogens, that were originally present in the mesophilic sludge, to become dominant under the new thermophilic conditions (Chachkhiani et al. 2004). In contrast when the $55^{\circ} \mathrm{C}$ reactor was shifted to a temperature of $37^{\circ} \mathrm{C}$ and the new set of stable conditions were established from days 132 onwards, these properties were different from those of either the initial properties of the $37^{\circ} \mathrm{C}$ or $55^{\circ} \mathrm{C}$ reactors (Table 5). A reduced amount of biogas production coincided with a significantly $[p<0.05]$ higher TVFA level (851.29 $\mathrm{mg}$ as acetic acid/L) even at day 146, when the experiment was terminated. This indicates that the new microbial consortium is probably different from that operating initially in the $37^{\circ} \mathrm{C}$ reactor and results in a population that is less efficient in terms of $\%$ COD removal, biogas and methane productions. This could be related to the poor development of mesophiles that should become dominant under the new mesophilic conditions. The results indicate that the microbial population present in the $55^{\circ} \mathrm{C}$ reactor found it more difficult to recover from temperature changes than did the population of the $37^{\circ} \mathrm{C}$ reactor. This indicates that temperature regulation here is complex and may depend on the composition of the initial sludge in the system. Lau and Fang (1997) found that a temperature shock had a less adverse effect on the acetotrophic methanogens than on other methanogens. According to Cabirol et al. (2003), who studied the adaptation of a mesophilic anaerobic sludge to thermophilic conditions, this also showed a rapid adaptation with an increase in the proportion of hydrogenotrophic methanogens.

We have shown that the adverse effect of a temperature shift can be alleviated by an initial lowering of the OLR. When this is followed by a slow increase back to the initial OLR value the system can return to a steady state that in some cases is not too different from the original but at a different temperature. We strongly recommend the use of this procedure in order to help microbial populations adapt to any temperature shifts. Moreover, a continuous feed should be used to eliminate problems that may arise from transient growth conditions and to permit flexibility in adjustment of the time course of temperature shifts. It also can be used to select a culture that will grow under conditions of stress.

\section{CONCLUDING REMARKS}

Based on these results, the operation of a $37^{\circ} \mathrm{C}$ reactor at an OLR of $10.74 \mathrm{~g}[\mathrm{COD}] / \mathrm{L} /$ day and the $55^{\circ} \mathrm{C}$ reactor at an OLR of $12.15 \mathrm{~g}[\mathrm{COD}] / \mathrm{L} /$ day equivalent to an HRT of 7 days is likely to achieve satisfactory results.

The $37^{\circ} \mathrm{C}$ reactor could tolerate temperature variations in the range of $37-43^{\circ} \mathrm{C}$ without significant changes in an index for process stability (TVFA and TVFA/Alkalinity) whereas, the $55^{\circ} \mathrm{C}$ reactor could tolerate temperature variations in the range of $55-43^{\circ} \mathrm{C}$. However, minor instabilities of the processes in terms of TVFA and TVFA/alkalinity were observed when the temperature was changed.

The first indication of a loss of stability of the processes, due to a temperature shift, in both reactors was an accumulation of TVFAs. This occurred at a temperature of $46^{\circ} \mathrm{C}$ for the $55^{\circ} \mathrm{C}$ reactor and at $40^{\circ} \mathrm{C}$ for the $37^{\circ} \mathrm{C}$ reactor.

The instability could be overcome by lowering the OLR. After the stability was regained the OLR could be gradually increased to that of the initial value, without major changes to the stability.

\section{REFERENCES}

AHMAD, Abdul Latif; ISMAIL, Suzylawati and BHATIA, Subhash. Water recycling from palm oil mill effluent (POME) using membrane technology. Desalination, August 2003, vol. 157, no. 1-3, p. 87-95.

AHN, J.-H. and FORSTER, C.F. The effect of temperature variations on the performance of mesophilic and thermophilic anaerobic filters treating a simulated papermill wastewater. Process Biochemistry, January 2002, vol. 37, no. 6, p. 589-594.

ANGELIDAKI, I.; PETERSEN, S.P. and AHRING, B.K. Effects of lipids on thermophilic anaerobic digestion and reduction of lipid inhibition upon addition of bentonite. Applied Microbiology and Biotechnology, July 1990, vol. 33, no. 4, p. 469-472.

BANERJEE, S. and BISWAS, G.K. Studies on biomethanation of distillery wastes and its mathematical analysis. Chemical Engineering Journal, September 2004, vol. 102, no. 2, p. 193-201.

BJÖRNSSON, L.; MATTIASSON, B. and HENRYSSON, T. Effects of support material on the pattern of volatile fatty acid accumulation at overload in anaerobic digestion of semi-solid waste. Applied Microbiology and Biotechnology, June 1997, vol. 47, no. 6, p. 640-644. 
BJÖRNSSON, L.; MURTO, M. and MATTIASSON, B. Evaluation of parameters for monitoring an anaerobic codigestion process. Applied Microbiology and Biotechnology, December 2000, vol. 54, no. 6, p. 844-849.

BORJA, Rafael and BANKS, Charles J. Comparison of an anaerobic filter and an anaerobic fluidized bed reactor treating palm oil mill effluent. Process Biochemistry, 1995, vol. 30, no. 6, p. 511-521.

BORJA, R.; MARTÍN, A.; BANKS, C.J.; ALONSO, V. and CHICA, A. A kinetic study of anaerobic digestion of olive mill wastewater at mesophilic and thermophilic temperatures. Environmental Pollution, 1995, vol. 88, no. 1, p. 13-18.

BORJA, Rafael; BANKS, Charles J. and SÁNCHEZ, Enrique. Anaerobic treatment of palm oil mill effluent in a two-stage up-flow anaerobic sludge blanket (UASB) system. Journal of Biotechnology, February 1996, vol. 45, no. 2, p. 125-135.

BOUŠKOVÁ, A.; DOHÁNYOS, M.; SCHMIDT, J.E. and ANGELIDAKI, I. Strategies for changing temperature from mesophilic to thermophilic conditions in anaerobic CSTR reactors treating sewage sludge. Water Research, April 2005, vol. 39, no. 8, p. 1481-1488.

CABIROL, N.; FERNÁNDEZ, F.J.; MENDOZA, L. and NOYOLA, A. Acclimation of mesophilic anaerobic sludge to thermophilic conditions: PCR genera detection methodology. Water Science and Technology, June 2003, vol. 48, no. 6, p. 81-86.

CAIL, R.G. and BARFORD, J.P. Mesophilic semicontinuous anaerobic digestion of palm oil mill effluent. Biomass, October 1985, vol. 7, no. 4, p. 287-295.

CHACHKHIANI, M.; DABERT, P.; ABZIANIDZE, T.; PARTSKHALADZE, G.; TSIKLAURI, L.; DUDAURI, T. and GODON, J.J. 16S rDNA characterization of bacterial and archaeal communities during start-up of anaerobic thermophilic digestion of cattle munure. Bioresource Technology, July 2004, vol. 93, no. 3, p. 227-232.

CHEN, Min. Adaptation of mesophilic anaerobic sewage fermentation populations to thermophilic temperatures. Applied and Environmental Microbiology, April 1983, vol. 45, no. 4, p. 1271-1276.

CIRNE, D.G.; PALOUMET, X.; BJÖRNSSON, L.; ALVES, M.M. and MATTIASSON, B. Anaerobic digestion of lipid-rich waste - Effects of lipid concentration. Renewable Energy, May 2007, vol. 32, no. 6, p. 965-975.

CLESCERL, Lenore; GREENBERG, Arnold E. and EATON, Andrew D. Standard Methods for the Examination of Water and Wastewater. $20^{\text {th }}$ ed.
Washington DC, American Public Health Association, 1998. 1000 p. ISBN 0-875-53235-7.

DE LA RUBIA, M.A.; PEREZ, M.; ROMERO, L.I. and SALES, D. Anaerobic mesophilic and thermophilic municipal sludge digestion. Chemical and Biochemical Engineering, 2002, vol. 16, no. 3, p. 119-124.

EL-MASHAD, Hamed M.; ZEEMAN, Grietje; VAN LOON, Wilko K.P.; BOT, Gerard P.A. and LETTINGA, Gatze. Effect of temperature and temperature fluctuation on thermophilic anaerobic digestion of cattle manure. Bioresource Technology, November 2004, vol. 95, no. 2, p. 191-201.

ERGÜDER, T.H.; TEZEL, U.; GÜVEN, E. and DEMIRER, G.N. Anaerobic biotransformation and methane generation potential of cheese whey in batch and UASB reactors. Waste Management, 2001, vol. 21, no. 7, p. 643-650.

GRIFFIN, Matt E.; MCMAHON, Katherine D.; MACKIE, Roderick I. and RASKIN, Lutgarde. Methanogenic population dynamics during start-up of anaerobic digesters treating municipal solid waste and biosolids. Biotechnology and Bioengineering, February 1998, vol. 57, no. 3, p. 342355.

IRANPOUR, O.; COX, H.H.J.; SHAO, Y.J.; MOGHADDAM, O.; KEARNEY, R.J.; DESHUSSES, M.A.; STENSTROM, M.K. and AHRING, B.K. Changing mesophilic wastewater sludge digestion into thermophilic operation at terminal island treatment plant. Water Environment Research, September-October 2002, vol. 74, no. 5, p. 494-507.

JENKINS, S.R.; MORGAN, J.M. and SAWYER, C.L. Measuring anaerobic sludge digestion and growth by a simple alkalimetric titration. Journal of the Water Pollution Control Federation, May 1983, vol. 55, no. 5, p. 448-453.

LAU, Ivan W.C. and FANG, Herbert H.P. Effect of temperature shock to thermophilic granules. Water Research, October 1997, vol. 31, no. 10, p. 2626-2632.

NAJAFPOUR, G.D.; ZINATIZADEH, A.A.L.; MOHAMED, A.R.; Isa, M.H. and NASROLLAHZADEH, $\mathrm{H}$. High-rate anaerobic digestion of palm oil mill effluent in an upflow anaerobic sludge-fixed film bioreactor. Process Biochemistry, February 2006, vol. 41, no. 2, p. 370-379.

OSWAL, N.; SARMA, P.M.; ZINJARDE, S.S. and PANT,

A. Palm oil mill effluent treatment by a tropical marine yeast. Bioresource Technology, October 2002, vol. 85, no. 1, p. 35-37.

PADILLA, R.B. and BANKS, C.J. Thermophilic semi- 
Choorit, W. and Wisarnwan, P.

continuous anaerobic treatment of palm oil mill effluent. Biotechnology Letters, July 1993, vol. 15, no. 7, p. 761766.

RAJ, D.S.S. and ANJANEYULU, Y. Evaluation of biokinetic parameters for pharmaceutical wastewaters using aerobic oxidation integrated with chemical treatment. Process Biochemistry, January 2005, vol. 40, no. 1, p. 165175.

RITTMANN, Bruce E. and MCCARTY, Perry L. Environmental Biotechnology: Principles an Applications. New York, McGraw-Hill Book Co., 2001. 768 p. ISBN 0072-34553-5.

SONG, Young-Chae; KWON, Sang-Jo and WOO, JungHui. Mesophilic and thermophilic temperature co-phase anaerobic digestion compared with single-stage mesophilicand thermophilic digestion of sewage sludge. Water Research, April 2004, vol. 38, no. 7, p. 1653-1662.

SPEECE, R.E. Anaerobic Biotechnology for Industrial Wastewaters. Nashville, Tennessee, Archae Press, 1996. 416 p. ISBN 0-965-02260-9.

WHEATLEY, A.D. Anaerobic Digestion: A Waste Treatment Technology. London, Elsevier, 1990. 234 p. ISBN 1-851-66526-9.

YU, Hang-Qing; FANG, Herbert H.P. and GU, Guo-Wei. Comparative performance of mesophilic and thermophilic acidogenic upflow reactors. Process Biochemistry, November 2002, vol. 38, no. 3, p. 447-454.

ZINATIZADEH, A.A.L.; MOHAMED, A.R.; NAJAFPOUR, G.D.; ISA, M.H. and NASROLLAHZADEH, H. Kinetic evaluation of palm oil mill effluent digestion in a high rate up-flow anaerobic sludge fixed film bioreactor. Process Biochemistry, May 2006, vol. 41, no. 5, p. 1038-1046. 